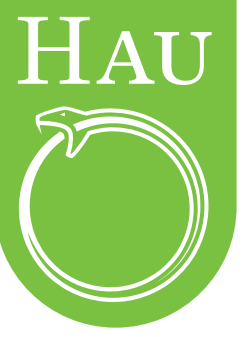

\title{
Governing the souls of Chinese modernity
}

\author{
Andrew B. Kipnis, Chinese University of Hong Kong \\ and Australian National University
}

Philippe Descola argues that human societies can be categorized by the ways in which they utilize broad assumptions about interiority and physicality, where interiority refers to something similar to what Edward Tylor and James Frazer meant by soul. In Descola's scheme, traditional Chinese culture, which gives play to infinite variability in both interiority and physicality, is strongly "analogist." In contrast, Descola defines modern, Western societies as "naturalist." We moderns see nature or physicality as universally fixed, but culture or interiority as variable. Contemporary China is rapidly modernizing and scientizing. In Descola's terms, its culture should be transitioning from an analogist one to a naturalist one. Through an examination of practices of memorialization and funerary ritual in urban China as well as Chinese Communist Party attempts to steer the evolution of these practices in reaction to "modernity," this essay attempts to tease out what is modern about the conceptions of soul implicit in contemporary Chinese dealings with death.

Keywords: China, death rituals, memorialization, Descola, soul, governing

In 1871, Edward Tylor (1871: vol 2, p.1) argued that belief in souls derived from visions of the dead seen in dreams. For "primitive man," Tylor saw this belief as universal. James Frazer likewise saw primitive belief in the soul as universal, but linked the phenomenon to the experience of death:

If an animal lives and moves, it can only be, [the savage] thinks, because there is a little animal inside which moves it: if man lives and moves it can only be because he has a little animal or man inside who moves him. The animal inside the animal, the man inside the man, is the soul. And as the activity of an animal or man is explained by the presence of the soul, so the repose of sleep or death is explained by its absence; sleep or 
trance being the temporary, death being the permanent absence of the soul. (Frazer 1978 [1911]:83)

Jumping forward a century, in a self-conscious revival of a much older style of anthropology, Philippe Descola argues that humans everywhere interpret the world through the categories of interiority and physicality, where interiority references more or less the same characteristics that Frazer and Tylor saw as soul: mind, consciousness, and intentionality (Descola 2013:116). For Descola, the categories of interiority and physicality derive simply from the universal experience of being an intentional subject with a body.

Descola's scheme discards the explicit evolutionism of Tylor and Frazer. Western moderns also utilize ideas about interiority when identifying other beings as similar or dis-similar. But the manner in which they do so is unique. As "naturalists" in Descola's fourfold ontological scheme, moderns see physicality or nature as having universal laws, but see interiority as variable. In the naturalist imaginary, other humans see the world through the lenses of different cultures, while animals have more limited interior capabilities. Nonmodern humans use three other modalities to categorize the beings of the world. Animists see all beings as having similar interiorities but differing physicalities; analogists see physicality and interiority as equally variant, while totemists see physicality and interiority as being shared by all. Though not explicitly evolutionary, the four varieties of society coalesce into distinct groupings: those who hunt and gather are overwhelmingly animists and totemists; those who farm and herd domesticated animals are analogists, and those living in industrial societies dominated by scientific thinking are naturalists. Descola further argues that historical transformations from one ontological mode to another often accompany but are not necessarily caused by "mutations in technological systems" (2013: 366), and he explores how the domestication of animals led to a transformation from animism to analogism among caribou herders in Siberia.

In this article I focus on the transformation of death ritual and memorialization in a modernizing, urbanizing, and scientizing China as well as the conscious attempts by Chinese communists to modernize the treatment of the soul in death ritual and memorialization. While remaining agnostic regarding debates about the origins of human notions of soul, I see death, death ritual, and memorialization as important moments for investigating the significance of soul to human society. Death is when the body loses its animating force; grief involves working through dreams and memories of the deceased; and memorialization necessitates immortalizing something of the spirit of the departed.

My use of the English term soul as a comparative category (as opposed to interiorities or a transliteration of a related Chinese term) is a deliberatively provocative act. It goes to the heart of the poetics and politics of this article. Three implications of the word are particularly useful. First, it bridges a religious/secular, modern/premodern, analogic/naturalist divide. Soul is often used in modern/secular contexts as in "soul music" or in the titles of scores of books on psychoanalysis, but its links to medieval Christianity resonate. Second, and relatedly, soul uses its connection to the premodern sacred to connote the relative permanence, power, and importance of the interiority it designates, even when referring to secular and modern entities. Tampering with someone's soul is a more serious affair than manipulating their 
"spirits," which might be high or low on a given day because of a variety of factors. While useful for comparing agencies across all types of human culture, the term interiorities is too bland for this article's political exploration of the blending of analogic and naturalist thought. Interiority lacks soul. Finally, soul allows me to invoke the work of Tylor and Frazer. The connotations of the word soul illuminate both my interpretation of Descola's scheme and my critique of the ideology surrounding the political regulation of funerary practice in China.

If China is seen as a country that is modernizing - that is transforming from a place in which the majority of people are farmers who live in villages to one in which the majority live in cities and work in a diversity of manufacturing and service sector jobs, that is undergoing a demographic transition, an increase in the number of years children spend in schools, and a rapid time-space compression-then this modernization must be understood as recombinant process (Kipnis 2016). That is to say, rather than seeing modernization as a switch from one thing to another, we must examine how aspects of the premodern are reconfigured in modern arrangements. In Descola's terms, we should see how the pieces of an analogic culture are restructured with the intrusion of institutions that favor naturalistic assumptions.

One question raised by Descola's scheme is whether modern transformations require a total shift. The scheme implies that differing ontologies are incompatible with one another and that a gestalt-like switch must occur at some point in a history of a gradual accumulation of naturalist assumptions. Descola portrays such a process in his depiction of the transformation of an animist system into an analogic one (2013: 365-77). Poststructuralists, however, would argue that humans are perfectly capable of harboring two or more conflicting and possibly contradictory schemas at once, ${ }^{1}$ and contemporary Chinese cultures of memorialization do mix analogic and naturalist ontologies.

Many of the critical readings of Descola published in this journal have emphasized the rigidity of his structural scheme and the difficulty of illuminating cases of ontological mixture this rigidity creates (see especially, Feuchtwang 2014; Kapferer 2014; Lenclud 2014). Descola himself wrestles with this problem in his response to these essays (Descola 2014). At a theoretical level, accepting the blending of analogic and naturalist thinking undermines overly logocentric and ontological readings of Descola. That is to say, if humans can blend contradictory ways of thinking in their actions, then the logics of a given scheme are considerably less binding on human action than structuralist thought might suggest and structural assumptions are in this sense less "ontological." Human practice itself rather than ideational schemes become generative. But even if naturalist and analogic ontologies can be blended, I still find these categories to vividly illuminate both the range of actions that take place in contemporary urban Chinese death rituals and the ideological debates surrounding them. In the context of the essays published in this journal, my use of Descola's theory to construct a political critique is more noteworthy than any criticism I have of the theory itself.

According to Descola, in analogic ontologies, where physicalities and interiorities both differ, resemblance becomes the primary method of creating order.

1. Vanessa Fong (2007), for example, makes such an argument with regard to Chinese morality.

\section{7 | HAU: Journal of Ethnographic Theory 7 (2): 217-238}


Elaborate hierarchies of beings are seen to exist, but resemblances among microcosms and macrocosms enable ritual specialists to grasp the universe. Socially complex kin systems and long genealogies of ancestors emerge alongside relatively simple systems of "humors," like yin and yang, which are used to manage the huge flux of singularities. ${ }^{2}$ Many aspects of premodern China's cultures of memorialization mark it as analogic. Its cult of the ancestors, its hierarchical view of the relationship between ancestors and descendants, its complex practice of ancestral sacrifice, and its detailed system for locating and orienting graves to bring prosperity to future generations all fit Descola's depiction of analogic societies. ${ }^{3}$

China's funerary culture differs radically from animist and totemic ones. Descola argues, "It is impossible not to notice that sacrifice is present in regions dominated by analogical ontologies (in particular Brahmanic India, West Africa, ancient China, where it was above all associated with political functions, the Andean zone, and pre-Columbian Mexico), whereas it is virtually unknown in totemic Australia and the regions that are, par excellence, animist, namely Amazonia and subartic America" (2013: 228). Sacrifice, for Descola, whether to heaven, a God, or one's ancestors is a way of creating a connection across a hierarchical divide. Animist and totemic societies are not hierarchical and thus find no need for sacrifice. In addition, animists and totemic societies typically lack significant regimes of property and patrimony. Where there is land to pass down to descendants, regimes of ancestral cults and unilineal descent become important. In analogic societies like premodern China, sons cannot inherit until they execute funerary rites (2013: 330). In Amazonia, there are neither ancestors nor significant memorialization (2013: 332).

A wide range of Chinese terms refer to various forms of interiority that might be translated as soul. These include but are not limited to jing (精), shen (神), hun (魂), po (魄), gui (鬼), ling (灵), and various combinations thereof. There are gods, ghosts, and ancestors of many varieties. There are the three hun and seven po of Taoism. In this article, I make no attempt to make sense of all of these distinctions except to note that Descola's depiction of the multiplicity of beings and agencies in the analogic imagination successfully summarizes the situation.

2. Stephan Feuchtwang (2014) emphasizes that analogisms differ and that one of the particularities of Chinese analogism is the emphasis on processes over singularities. While agreeing that systemic thought in traditional Chinese science emphasizes processes, I would argue that singularities emerge in the thought of nonscientific thinkers in most places, including contemporary China.

3. William Matthews (2017) convincingly demonstrates that scientifically oriented diviners in China deny the distinction between interiority and physicality and thus he categorizes their thought as homologic rather than analogic. He further suggests that homologic ontologies are common among systematic thinkers, including Western scientists and many anthropologists. But Matthews also suggests that analogic thinking is common in China outside of philosophically oriented circles. I note both that systematic thinkers are more likely to come up with unified ontologies than others and that analogic thought-within which physicalities and interiorities are equally variant-perhaps blends into homologic ontologies more readily than naturalist or animist thought. Totemic thought might similarly be considered relatively compatible with monist or homologic schemes, as Ute Eickelkamp (2017) suggests.

2017 | HAU: Journal of Ethnographic Theory 7 (2): 217-238 
More modern and perhaps more naturalist in their implications are the compounds linghun and jingshen. Linghun is typically translated as soul and jingshen as spirit. As in English, the term linghun/soul connotes an entity more powerful and permanent than jingshen/spirit. But unlike English, the terms can reflect a modernist critique of religious "superstition." Linghun often implies something supernatural while jingshen is used in secular phrases-like the spirit of Lei Feng (i.e., a spirit of hard work and self-sacrifice), ${ }^{4}$ or "that blouse is (makes you look) spirited" (neige yifu ting jingshen). My use of soul as a comparative term runs against and is meant to critique this particular distinction in Chinese. I justify my translation with a phrase from Chinese Communist Party (CCP) propaganda: "the soul of the Party" (dangde linghun). If linghun designates something that is supernatural, then how is it that the chief architect of secularist, antireligious ideology in China today credits itself (as well as various aspects of its being, like Marxist thought, or the socialist legal system) with having one? The answer is that Party propagandists mirror the poetics of the English language by using linghun's sacred/religious connotations to imply that there is something permanent and powerful about the interiority that animates the Party. The Party's critique of superstition in death ritual, and the related connotations of the jingshen/linghun distinction, reflect its desire to state that only the Party has an animating interiority important enough to be designated as a soul. By using soul as a catchall comparative term for divergent forms of animating interiority, I reject this particular claim.

Because of limitations of space, Descola omits regimes of temporality from his analysis (2013: 114), but conceptions of time are important to practices of memorialization. As Jason Danely defines it, memorialization involves "practices that recognize the mutual interdependence of the living and the spirits of the dead" (2014: 3). By definition, such practice requires positing that the spirit of the deceased persists in time beyond the demise of the body. In both analogic and naturalist societies, memorialization often implies that the soul or spirit of the deceased is permanent, immortal, or transcendent. For example, in China, as in many places, memorial markers are carved or set in stone, representing their relative permanence. In premodern China, emperors often erected large stone tombs for themselves; over the twentieth century, the use of stone gravestones spread across many sectors of society, and in the twenty-first century, the majority of the deceased have their names carved on a tombstone (what Thomas Laqueur [2015] call necronominalism; see also Kipnis [forthcoming]). Funerary rites likewise invoke a world where the soul exists forever. When donating flowers or giving a gift to the family at or before a funeral, Chinese urbanites will often have a couplet written for them to express their relation to the deceased and to ask for the soul to last forever, such as "Magnificent Uncle (father's younger brother) last forever, your nephew, Kean” (叔叔大人千古, 侄儿柯安; Shushu Daren Qiangu, Zhier Kean). The fact of death, however, forces us to recognize that human bodies are transient. Memorialization thus often involves a linking of tropes of transcendence with experience of transience. Whether done explicitly or implicitly, narratives that link the two

4. Lei Feng was a model soldier who kept a diary that recorded his constant efforts to do good deeds and sacrifice his own time, energy, and well-being for the sake of others. Note that in English, spirit, like soul, can refer to both natural and supernatural entities.

\section{7 | HAU: Journal of Ethnographic Theory 7 (2): 217-238}


modes of temporality dominate interaction with the dead. In modern societies, particular functional and political logics surround these narratives, and analogic societies provide many cultural resources for these narratives to draw upon.

\section{Death ritual in China today}

As with most things in China, the state plays an important role in contemporary Chinese death. It promotes and often demands cremation, and it attempts to outlaw or discourage what it considers to be feudal practices. As is the case with the birthplanning policy, however, one could debate the extent to which it is mandating or encouraging practices that would anyway emerge in the course of modernization, without heavy-handed state intervention. ${ }^{5}$ Throughout East Asia, urbanization and the resulting decrease in space for burials as well as decreases in the sizes of households and kinship networks, have resulted in increases in rates of cremation and less lavish funerals.

Funerary practice differs across China with rural/urban differences highlighted by my interviewees. Rural people often have access to land on which to bury their dead without purchasing plots in graveyards, and rural people are more likely to bury dead bodies without cremation. While these differences are important, antirural prejudices often emerge in urban castigations of rural funerary practice. While rural people sometimes resist cremation, it is also true that many poor rural areas lack adequate crematoriums. In China as whole, between 1999 and 2003, as the number of crematoriums grew from 1,318 to 1,515, the overall cremation rate increased from 42 to 53 percent. In large urban areas and wealthy eastern provinces, nearly 90 percent of bodies are cremated (Chen and Chen 2008:265).

In large cities, non-Muslim families must cremate bodies at a state-run crematorium. Most people will hold a "farewell ceremony" (告别会; gaobiehui) just before cremation. The body is displayed in an open casket and there are opportunities for speaking, bowing to the deceased, and consoling immediate family members. The body is then cremated and the family receives the ashes in a cinerary casket (骨灰 盒; guhuihe). The casket is most often buried in a graveyard. A minority chooses to scatter the ashes at sea or in a river, or dispose of the ashes in some other manner, but the ashes must be disposed through a state-sanctioned process. The private disposal of ashes without state approval is illegal. Urban funeral homes are usually located at the same place as the crematorium and are always run by the same state agency (the Ministry of Civil Affairs [民政局；Minzheng Ju]) that runs the crematoriums. The Ministry runs many urban graveyards as well, though in some urban areas there are also privately managed graveyards, run by large corporations that have been approved by the Ministry. Illegal and quasi-legal graveyards (often run

5. Because the birth-planning policy resulted in so much intimate intervention in women's lives and such severe consequences (e.g., forced abortions and sterilizations, fines equivalent to many years of a household's income), this debate has considerable implications for the legitimacy of the Party (Greenhalgh 2003; Greenhalgh 2008; Greenhalgh and Winckler 2005; Wei and Zhang 2014; Whyte, Wang, and Yong 2015).

2017 | HAU: Journal of Ethnographic Theory 7 (2): 217-238 
by villages on their own land but quietly opened to outsiders) have less expensive burial plots, but exist under the threat of state demolition.

Rituals may be held at many points during the funerary process and a wide variety of specialists can be employed. There can be rituals at the home or hospital where the person dies; rituals when the body is transported from the point of death to the funeral home; rituals when close friends, neighbors, and relatives come to visit a home altar for the deceased and pay respects to close family members before the funeral itself. After the farewell ceremony, there can be rituals when the cinerary casket is buried, banquets for close family members who attended the funeral, rituals marking various periods after the death, and rituals of grave sweeping during annual visitations at Qing Ming (April 4 or 5), the winter solstice, and certain days marked by the Chinese lunar calendar. These rituals are usually held at graves but can also be conducted at temples, mosques, and churches. In large urban areas, small private businesses offer to arrange the entire funerary process, securing death certificates and necessary government paperwork, arranging appointments for cremation and the farewell meeting at the funeral home, writing obituaries, and setting up an altar (灵堂; lingtang) in the home where guests can be received before the funeral, recommending graveyards, and providing introductions to whatever ritual specialists the family would like to employ. These entrepreneurs often advertise their businesses as a "one-stop dragon" (一条龙; yi tiao long) service because they cover the process from start to finish.

While religious specialists may be used in death rituals, in the large cities of Nanjing and Jinan, my best guess (based on interviewing one-stop dragon entrepreneurs) is that in over 95 percent of funerals, they are not. Most families have a secular master of ceremonies at both the farewell meeting and when the cinerary casket is buried. However, especially at the burial, the master of ceremonies often conducts a ritual with elements derived from a more analogic past. Families generally follow the master of ceremony's directions, without commenting on whether aspects of the ceremony might be considered secular, religious, or superstitious. Families exert more agency when they receive guests at the home altar or visit the grave after the funeral proper. They often bring sacrificial offerings, flowers, and spirit money while speaking aloud to the deceased at the grave.

State regulation of this convoluted process takes many contradictory forms. Some practices, including the burying of uncremated bodies, are simply banned. The city of Nanjing recently also prohibited the use of firecrackers (to scare away unwanted ghosts). Such bans, and the lengths taken to enforce them, vary by jurisdiction. Members of propaganda bureaus often write books and papers encouraging the simplification of funerary ritual and the ending of all superstitious and religious practices, which would practically end all of the activities described above. Government agencies sometimes arrange funerals for their former employees, or give the family members of the deceased some monetary assistance and practical guidance. Party cadres in charge of such work advocate simple funerals. Other government agencies (typically the community office [社区; shequ]) arrange basic funerals for impoverished households or for elderly who do not have relatives. The funeral homes, graveyards, and crematoriums run by the Ministry of Civil Affairs are in a more contradictory position. On the one hand, they too are supposed to discourage superstition and promote "civilized" funerals. Very often, as part of the

\section{7 | HAU: Journal of Ethnographic Theory 7 (2): 217-238}


government, they must accept limits on the prices for their most basic services such as cremations and burials in collective plots without gravestones. On the other hand, they are responsible for their own profits and losses, and are constantly on the lookout for ways to offer extra services. Some of the resulting pricing strategies are quite contradictory. For example, in Nanjing, rental rates for a small farewell meeting room are only 100 yuan (less than \$20) per hour, but the price to decorate the room with layers of flowers wreaths range from 3,000-50,000 yuan. ${ }^{6}$

Tensions over funerals pervade the Party itself. As powerful people with access to state-funded funerals, the families of high-ranking cadres often hold some of the more lavish funerals in China. On the other hand, as exemplars of Party policy, they sometimes come under pressure to hold relatively simple funerals. Since $\mathrm{Xi}$ Jinping came to power and began his anticorruption drive in 2013, funerals for deceased Party cadres have become less spectacular. In Nanjing, funeral home workers told me that spending on the funerals for mid- to high- ranking cadres decreased from about 200,000 yuan in 2012 to about 50,000 yuan in 2014 (this price would not include a gravesite; an average funeral in Nanjing cost in the range of 10,000-20,000 yuan that year). In 2016, the Party further tightened regulations about the family rituals of Party members. In the city of Harbin, for example, funerals for the parents of party cadres were supposed to be limited to 100 people, all of whom must be relatives (Piao 2016; Zhao 2016).

While urban funeral homes have the capacity to hold large funerals for prestigious people, both one-stop dragon entrepreneurs and workers at state funeral homes in Nanjing and Jinan told me that the average size of urban funerals has decreased over the past decade. They suggested several reasons for this decrease. First, people are living longer. Extremely old people have fewer friends because some of their friends have already passed away, while others cannot leave their homes to attend a funeral. Second, as society has become more mobile, people are less likely to be close friends with their neighbors and are more likely to have relatives who live in other cities.

But some funeral workers felt that the size of funerals was not decreasing in rural areas. In the rural areas within the boundaries of Nanjing, families must cremate the bodies of their loved ones before burying the cinerary casket in a village graveyard. But other than the cremation itself, rural families have very little to do with the state-run funeral home. After death, they keep the body at home (in a refrigerated casket if necessary) for between three and seven days, while friends and relatives drop in to pay their respects. Everyone who comes gives a (cash) gift and is treated to a banquet. A one-stop dragon entrepreneur told me of a rural funeral where he arranged for over 100 banquet tables (enough for 1,000 people) and kept them in service for five days straight. He said that several thousand people consumed more than five thousand meals. The deceased had five children, all of whom were involved in successful businesses and had widespread social networks. But he also argued that even rural families without widespread networks would host banquets for all of the people in their village who were willing to attend, so even small rural funerals were larger than average urban ones. Although mobility

6. Jonathan Kaiman (2015) discusses some of the crass attitudes on display in state-run crematoriums.

2017 | HAU: Journal of Ethnographic Theory 7 (2): 217-238 
has increased across both rural and urban areas, rural villages, even in peri-urban areas, are more likely to house people who know their neighbors and are related to them. One funeral home worker in a peri-urban state crematorium complained to me, "Rural people don't spend a penny to purchase our services. In fact, because we have to perform basic cremations at subsidized rates and often provide free cinerary caskets and transportation of the deceased's body to the crematorium, we spend money on them. But they aren't poor. They can spend over 100,000 yuan on the banquets and superstitious rituals they carry out in their homes. And even when they spend so much, they often make money after you consider all of the gifts they receive."

While such accounts of rural funerary practice reflect both a degree of antirural prejudice and situations particular to the peri-urban rural areas around large eastern cities, they do show some of the directions in which differences in funerary practice are evolving across the rural/urban divide. They also speak to the similarities. In both rural and urban areas, the number of people who attend a funeral reflects the social and economic status of the family of the deceased.

Like funerary ritual, urban graveyards are sites of considerable class distinction. One way of identifying an elite graveyard is to examine the prevalence of ecoburials (生态葬; shengtai zang). Eco-burials involve ways of disposing of ashes that use less land than a standard grave with a tombstone, and it is official policy to encourage them. They include wall burials, in which small sections in a high wall are reserved for individual cinerary caskets, with the name of the deceased and the surviving relatives carved in a small piece of stone as if it were a tombstone; vault burials, in which thousands of cinerary caskets are placed in a deep underground vault with a pagoda on top of it, with the names of the deceased etched on the pagoda walls; and tree burials, in which the biodegradable cinerary caskets are buried in front of a tree with no marker. In most graveyards, very few people purchase ecoburial sites. In the most prestigious graveyards, however, many people purchase eco-burial sites, even though they cost several times the price of a regular gravesite at a less prestigious graveyard. Those who choose such burials explain their choice in terms of burying their relatives in a "good neighborhood." Graveyard employees said that willingness to purchase eco-burial sites reveals the heightened consciousness and high "quality" (素质; suzhi) of the people who choose to bury their relatives there.

Some prestigious graveyards used to be sites reserved for high-ranking state cadres and national martyrs (烈士; lieshi). They have been recently opened up to anyone willing to pay a high price for a gravesite. Others were developed in the past decade or so, but managed to establish themselves as elite after the managers successfully offered free burial plots to the families of various political leaders, celebrated entrepreneurs, and famous entertainers. Still other graveyards became elite after earning the reputation of having a location with particularly favorable feng shui (geomancy). But once a graveyard is established as exceptional, the high prices it can charge for its burial sites will keep out the masses.

Elite graveyards often segregate their burial plots into sections for people from different walks of life. One section, for example, may be reserved for military men while another is reserved for cultural elites. Tombstones in such graveyards often give information about the career of the deceased, listing major accomplishments

\section{7 | HAU: Journal of Ethnographic Theory 7 (2): 217-238}


and sometimes including carvings or etchings of something from the deceased's professional life - a guitar for a musician or a book for an author. In contrast, tombstones in nonelite graveyards mostly display information about the familial connections of the deceased-the names of the family members to be buried together, the names of the surviving family members who purchased the gravestone and their relationship to the deceased, and occasionally homages to the deceased for being a loving mother, a caring father, or a devoted grandmother, or a cross if the deceased was a Christian.

Yu Hua's novel The seventh day depicts seven days of events from the perspective of the soul of a recently deceased man. He attends his own funeral, attempts to understand the cause of his death, and chases up the mysteries of his childhood. The novel posits that seven days is the period after death during which the soul can clearly perceive events in the human world and travel freely in search of answers. The novel sarcastically details all the forms of social hierarchy that are imposed on death. Most souls wait for their bodies to be cremated for long periods in uncomfortable waiting rooms with hard plastic seats. But VIPs enjoy shorter waits in comfortable lounges with leather sofas. Yet, even the VIP souls argue among themselves for the privilege of being the first body cremated for the day, thus avoiding the pollution from previous bodies. Most VIPs in the novel are state officials, and their rank in life largely determines their treatment in death. But the novel also explores how wealth influences death rituals. For example, some hire Buddhist monks to chant sutras for a deceased soul. The extremely wealthy pay extra for chanting that effects rebirth in the United States. The novel ends with a nod to equality. The world of skeletons where souls reside after the seventh day has no burial sites, no clothes, no hierarchy, and no distinguishing markers of any kind. Nevertheless, hierarchies structuring funerary rituals and acts of memorialization pervade Chinese society in both its rural and urban, and both its analogic and naturalist varieties.

\section{Memorialization, transcendence, and transience}

As Katherine Verdery notes in her analysis of the reburials and the toppling of memorial statues that occurred in the wake of the breakup of the Soviet Union, "Dead bodies have enjoyed political life . . . since far back in time" (1999:1). In China during the past few decades, there has been no regime change as dramatic as those that took place in Eastern Europe, but the politics of commemoration remain intense. At the Babaoshan Revolutionary Cemetery in Beijing, China's cemetery for national leaders, heroes, and martyrs, bodies-or more recently, cinerary caskets-have been dug up, removed, and relocated a surprising number of times. The former Cultural Revolution-era Vice Chairman Kang Sheng, for example, was exhumed from the cemetery at the same time as he was expelled from the Party. Conversely, He Long died ignobly during the Cultural Revolution in 1969, but was posthumously reinstated into the Party in 1975. The Party then relocated his cinerary casket to the Babaoshan Columbarium that same year (Wang and Su 2011).

7. Yu Hua (2013); for the English translation, see Yu (2015).

2017 | HAU: Journal of Ethnographic Theory 7 (2): 217-238 
Such dramatic events focus attention on the forms of transcendence or immortality upon which political regimes rely. The lives of certain founders or heroes come to represent the political soul of a particular regime or movement. Regime change thus requires a toppling of this soul. But even in times of political stability, when regimes are stable and graves and memorials rest in peace, the soul of political movements continues to evolve. In an essay on the "necropolitics" of selfimmolation by monks in Tibet, Charlene Makley (2015) avoids the intense politics of Chinese state/dissident monk contention by examining the subtle differences among interpretations of self-immolation by diverse people within the Tibetan community. Although the following examples are less politically charged than Makley's, they too suggest the ways in which funerary ritual is designed to permit reinterpretation while suggesting an air of immutability.

Consider first the practice of political education at the Babaoshan Revolutionary Cemetery. Students are routinely taken through the cemetery to have their patriotism reinforced by learning the stories of martyrs who sacrificed their lives for the Chinese nation. The ability of political educators to frame such lessons in a manner that resonates with the politically correct themes of the present relies on three mundane devices. First, many people are buried there. The political educators can take the students to the graves of those whose life stories most closely fit current concerns. When I visited the graveyard in September 2015, military men who had died in the war against Japan were highlighted. Second, interpretive signposts were placed in front of the graves that the educators discuss. These signs provide a relatively flexible medium for framing the words carved in stone on grave markers. Finally, a gigantic television screen was installed so that recently re-edited stories of the deceased's lives could be presented.

The flexible contextualization of "words carved in stone" is enabled in many Chinese graveyards today through the use of two dimensional matrix codes (二维 码; erweima) on tombstones. Such marks enable visitors to immediately download a life history of the person buried there on their smartphones. Needless to say, the life history that is saved in cyberspace can be amended as necessary.

But even the words carved onto tombstones are chosen to be reinterpretable while masking the shifting nature of their referents. The sales offices for most graveyards have photographs of various styles of gravestone and lists of suggested words and phrases for etching onto tombstones. These phrases reveal three strategies. The first is to mask the ways in which the meanings of the words might shift over time with references to eternity. Phrases like never forget (不忘; buwang), never ending (无绝期; wu jueqi), ever existing (永存; yongcun), and everlasting (永在; yongzai) are ubiquitous. The second strategy is to use words that refer to a type of abstract but easily accepted ideal persona or virtue-kind mother, caring father, loyal party member. While it is possible that the words these virtues invoke will fall out of style, they are also easy to reinterpret. What makes someone a good parent or a loyal friend can be retold in different ways. The third strategy is to choose words that enunciate relatively simple statements of fact-when a person was born, when they entered the Party, awards received. These statements can be used within a variety of narrative structures. There are limits to reinterpretation that make revolution and the consequent tearing up graves and memorials sometimes seem necessary. If, as may have been the case during the Cultural Revolution, the very idea of being

\section{7 | HAU: Journal of Ethnographic Theory 7 (2): 217-238}


a good parent is called into question, then the desecration of graves that declared someone to be a good parent might seem like a good idea.

Sometimes the relation of the eternal to the transient is explicitly mapped on the gravestone. One device for doing so involves the colors in which names are etched into tombstones. Most Chinese graves are designed for elderly couples rather than for individuals. The name of the first member of the couple to pass away is often written in black (or now sometimes in gold leaf), while the remaining member's name will be in red until that person passes away. In addition, the surnames remain in red, even after the person passes away. This indicates that family names are eternal, even though individuals are mortal. The individual is thus framed as a person whose life has been devoted to the cause of the family; women, perhaps unintentionally, are framed as having contributed primarily to their natal families. The practice of burying couples together also suggests that marriage itself transcends death. Thus, common folk too combine ideologies of eternity with the facts of mortality.

Another sort of reinterpretation of the lives of revolutionary martyrs takes place through the development of so-called red tourism. Many Chinese localities try to establish themselves as sites of red tourism by claiming the right to erect memorials to the deceased revolutionary martyrs and national leaders who were born there. This trend is especially prevalent in Hunan province, the birthplace of Mao Zedong, and thus a center of red tourism. In 1999, Peng Dehuai's cinerary casket was dug out of Babaoshan and returned to Xiangtan in Hunan where a memorial hall was built around his new grave and his former residence was reconstructed as a tourist site. In 2009, He Long was similarly returned to He Long Park in Zhangjiajie, Hunan, while one of the "old five" members of the communist party, Lin Boqu, was returned to Lintan in Hunan in 2013 (Liu 2014). While the new memorials in Hunan undoubtedly reproduce politically correct biographies for these famous past leaders, they can do so in a manner that gives more emphasis to the role of their birth locality in developing their revolutionary personas. ${ }^{8}$

One reason that the central government allows its martyrs to be removed to red tourist sites outside of Beijing is that the Babaoshan cemeteries are full. In reaction to full cemeteries as well as the price of land and housing in big cities, the Party issued new rules about promoting eco-burials for Party members in 2013. While eco-burials save land, they also reflect the maturing of the regime. As a regime ages, the founding leaders are immortalized but those of the middle periods become less important. Contemporary leaders establish rhetorical links to the founding fathers, while ignoring their more recent predecessors. As the rewriting of history loses its emphasis on the recent past, their historical distance from the present enhances the political sacredness of the original leaders. The lack of living memories of their presence makes the rewriting of their biographies easier.

Rather than linking explicit permanence to implicit transience, some funerary rites highlight transience, while implicitly tying this change to something eternal. A Buddhist priest once explained to me the reason for chanting sutras on behalf

8. Heonik Kwon (2006) provides an insightful analysis of Vietnamese state reburials and the relationships between local interpretations of the war dead to those of the national government.

2017 | HAU: Journal of Ethnographic Theory 7 (2): 217-238 
of the recently departed. The soul of the departed can hear the chanting and it helps them to make the journey to Western Paradise. He emphasized that it was important for the family members to not cry. "Crying makes the soul of the deceased less willing to leave this world and transition to Western Paradise. It creates unnecessary attachment. Birth and death are all part of life. Without death there could not be birth. We monks never cry at the funerals of our brethren." But if life is presented in Buddhist ritual as transient, both the soul and Western Paradiseespecially as they are popularly imagined-transcend. As Jason Danely explains regarding the memorialization of the deceased as both an ancestor and a Buddha, "Japanese Buddhism, like that found in China and Korea, is Mahayana, emphasizing the role of saint-like bodhisattvas whose compassion and wisdom provide the key to salvation without the necessity of numerous cycles of rebirth and merit accumulation more typical in Theravadan Buddhist cultures such as Sri Lanka or Thailand" (Danely 2014:29-30).

In China, the most famous dead body of all is that of Mao Zedong, whose mummified corpse is preserved in his mausoleum in Tiananmen Square. As Geremie Barmé (1996) points out, Mao's legacy has been reinterpreted by a wide variety of actors for a wide variety of purposes both within and outside of China. For the first time since the 1990s, I revisited his mausoleum in September 2015, at 8 a.m. on a Thursday morning, and was struck by three aspects of how the presentation of his persona had evolved (see Wakeman [1988] for a description of a Mausoleum visit in the 1980s). First, the entire square had been redesigned for tourists from the Chinese hinterlands. In the crowds of thousands of people milling about the square with me that morning, I saw not one non-Chinese face. Many of the people there were dressed in a manner that suggested that they came from the countryside. The square itself had been redecorated with a nearly life-sized, plastic flower and bird covered Great Wall replica. The replica allowed tourists to get a perfect photo of a Great Wall-like structure without actually going there. Its pristinely clean but plastic construction marked it as designed to appeal to rural rather than urban tastes.

Second, the presentation of Mao has made him more God-like. While a sacred attitude toward Mao's body was always encouraged, the mausoleum used to take more steps to encourage an appropriately secular communist attitude. ${ }^{9}$ Recently, there has been slippage in the direction of presenting Mao as a God. Entrants to the mausoleum must now take off their hats and remain silent. In addition, on my 2015 trip, all of the visitors I saw bowed three times before his statue at the entrance of the mausoleum, before placing flowers (sold for three yuan at the entrance) in the cauldron in front of his statue. The act both resembles and distances itself from the standard way one worships at a Chinese temple. The bows replace kowtows and the flowers replace burning incense. Thus, the communist ritual simultaneously declares itself different from "superstitious religions" while mimicking its form (for more on the deification of Mao see Wardega 2012). Finally, upon exiting the mausoleum, one is faced with a variety of stands selling Mao tourist kitsch. There are both official stalls within the cordoned off area of the mausoleum and unofficial stalls outside. Even the official stalls sold Mao badges and emblems of a type that

9. The tensions between communist and "feudal" elements in the very design of the mausoleum are discussed by A. P. Cheater (1991).

\section{7 | HAU: Journal of Ethnographic Theory 7 (2): 217-238}


seem to be a blasphemy against Mao's virulent anticapitalism. One 20-yuan goldcolored badge, for example, was decorated with a circle of fake diamonds and had a giant 福 ( $f u$, prosperity) character printed on the back side. While there have long been Mao badges that present him like a God of Wealth, to see them for sale at an official tourist stall next to his Mausoleum on Tiananmen Square struck me as indicative of a new degree of official acceptance of this reinterpretation.

Governments often frame their memorials in a chronotope of eternity. Carved in stone at the entrance to Mao Zedong's Mausoleum, as on many Chinese tombs, is the stock phrase remain forever without deterioration (永垂不朽; yongchui buxiu). As with the selection of words for tombstones, it is not just that words suggesting eternity are used but also that efforts are made to fix words flexible enough to last an eternity. Such a linguistic strategy applies to official funerals as much as tombstones. A cadre in charge of funerary arrangements for retired officials at a university once described to me the care taken with official obituaries. While no obituary can say anything bad about the deceased, the subtle gradations of positive words must be calibrated to match the rank of the retired cadre. "Fixing the words when you close the coffin” (盖棺论定, gaiguan lunding) is a Chinese tradition, this cadre concluded. While immortalizing the souls of their cadres, the CCP thus also seeks to immortalize the hierarchies created through their political rankings (see also Tsai 2017).

Tropes of permanence comfort us when death confronts us with our own mortality, fragility, and impermanence. They are also useful for political regimes that wish to project an image of invulnerability. But they should not fool us into thinking either that any regime or soul is permanent, or that the only pathway to change requires a revolutionary toppling of memorials. Death rituals and memorials, whether in the public political realm or a more private familial one, link tropes of transcendence with those of transience.

\section{The arguments of communists}

Despite the efforts made to immortalize the spirit of the CCP, officially endorsed attitudes toward funerary ritual are dismissive. In academic books about funerary ritual (Chen and Chen 2008; Wang 2002), the slogan thick care, thin burials (厚养 薄葬; houyang bozang) is often repeated. The phrase suggests generous care of the elderly in life as an alternative to lavish funerals. These works present the culture of elaborate funerals as stemming from the intersection of numerous historical forces, including belief in the immortality of the soul (灵魂不灭; linghun bumie); experience with the regenerative power of soil in an agrarian civilization and the resultant belief that earth burial results in a peaceful resting place for the soul, as captured in the saying "entering the earth is peace" (入土为安; rutu weian); a Confucian morality that emphasizes filial piety in both life and death; the social structures of lineage organizations with their elaborate ancestral cults; the political ideologies of emperors who linked filial piety to respect for the emperor; a hierarchical society that encouraged conspicuous display at funerals; and forms of Buddhism and Daoism preoccupied with a smooth transition to another world (Wang 2002).

In treatises that advocate thick care and thin burials, modernity is imagined as inevitably leading to simple funerals. Modernity leads to a rejection of a social

2017 | HAU: Journal of Ethnographic Theory 7 (2): 217-238 
structure organized around lineages and the development of one centered on the nation and society at large. Science demands rejecting belief in spirits. Nonagricultural societies can dispense with notions of "entering the earth is peace," and demonstrate more care about saving the resources of the earth (Wang 2002:203). Although these writings suggest that modernity will bring about ritual change in itself, they also demand that the Party take the lead in guiding society through this modernization. As such, they find it necessary to criticize those who hold large funerals. These writings suggest that holding expensive funerals often reflects guilt about not taking good care of one's elderly relatives in life; a fancy funeral makes a public display of one's filial piety when in private one's filial piety was lacking. They also dismiss lavish funerals as a mode of conspicuous consumption for the vainly status conscious.

I find most of these arguments to be one-sided. The criticisms of funerals as a form of consumption would be true about any other type of consumption. The automobile industry, for example, is highly supported by the government. But expensive cars are also status symbols and cars cause more pollution and waste than graves. So why are these reasons to criticize the funerary industry and not the automobile industry? If the automobile industry employs people, so does the funerary industry. The arguments about funerals as a form of superstition also seem superficial. Yes, funerary ritual in China can involve all manner of ghost, spirit, ancestor, God, and beliefs not proven by science, but funerary ritual in even the most modern and secular corners of society must speak of something spiritual. Thus, the specific ritual reforms suggested by the Party in the name of resisting superstition-substituting bows for kowtows, bringing flowers instead of burning spirit money, switching from more traditional funerary clothing (披麻戴孝; pima daixiao) to black armbands-seem more about form than substance. In the contemporary period, they often also reinforce antirural prejudice.

I once interviewed a cadre in charge of funerals for retired cadres who repeated most of the official arguments described above. When I pressed him about why flowers should be considered less superstitious than spirit money, he declared, "I am a materialist," as if that explained everything. Materialism is one of the keywords of Chinese Marxism. It both reflects the idea that science is opposed to superstition and reconfirms Marx's rejection of Hegel's "idealism." The terms idealism and materialism in Chinese seem even more extremely oppositional than they do in English. Materialism is rendered as "a belief in only concrete objects" (唯物主义; weiwuzhuyi) and idealism or spiritualism as “a belief in only ideals" (唯心主义; weixinzhuyi). If the Chinese Communist Party only believes in concrete objects, and if all Chinese funerary ritual invokes some sort of soul that transcends death, then why does the Party need to hold funerals for its own members? Why does it need graveyards for revolutionary martyrs and a mausoleum for its founding father?

Scholars of Chinese religion have detailed the roots of Chinese communist secularism in the semicolonial modernity of the late Qing dynasty (van der Veer 2012; Yang 2008), noted the scientistic excesses of and the religious influences on this secularism (Chau 2011; Goossaert and Palmer 2011; Ji 2011; Kipnis 2001; Kwok 1965), examined the contradictions between materialism and idealism in Chinese communist practice (Kipnis 2008), and introduced the vast expansion of religiosity

\section{7 | HAU: Journal of Ethnographic Theory 7 (2): 217-238}


during the reform era and the resultant compromises official secularism has made with religious practice. Officially expressed attitudes toward funerals were an extreme variant of this scientistic and ideological secularism; they offered little acknowledgement of the complexity of actual practice and the spaces opened up for this complexity during the reform era, and ignored the memorialization practices of the Party itself.

\section{The souls of modernity}

Like Tylor and Frazer, official communist attitudes propagate an evolutionary schema in which the need for belief in the soul ends with modernity. With Descola, I believe that modernity has influenced the shape of our belief in souls but has not reduced our need for some sort of interiority. But beyond Descola, I also argue that the analogic souls of a premodern era and the naturalist ones of a modern one are not so distinct. What, then, are the souls of modernity, or more specifically, Chinese modernity?

The tombstones, memorials, and funerals discussed above provide some clues. Modern political parties and leaders require an attitude, spirit, discourse, or ideology that consolidates the popularity or legitimacy of their cause, movement, or political persona. To use the language of Ernesto Laclau and Chantal Mouffe (2001), politics requires an "articulatory practice" and articulatory practice requires symbolic nodal points to rally around. ${ }^{10}$ Abstract symbols or ideals suture over both the gaps between the political interests and stances of different people, enabling the formation of coalitions, and the gaps in political formation left by death and the transience of individual lives.

Beyond the level of Party politics, Chinese practices of memorialization reveal a continuing analogic faith in an afterlife and the ghosts, gods, and ancestors who inhabit and govern the realms of the deceased. At the same time, however, popular practice also evinces two or three types of modern, naturalist soul. The first and most common one is that of the family itself. As the tombstones depicted above reveal, although the individual perishes, the family lives on. The second, for those who enjoy more than just a series of jobs, is the spirit of the career. A teacher, or doctor, or anthropological researcher dedicates himself or herself to an abstract calling that transcends any individual life. The third, if it is to be a separate category, sits somewhere between the first two, and speaks to those who identify with a particular religion, ethnic group, or manner of inhabiting the earth. The devoted Christian, ping-pong player, or calligrapher might consider their devotion a matter of personal calling, a political identity, or something altogether different.

Funerals are for the living and the grief of living moderns must be consoled with a reason for living, a reason that is first attributed to the soul of the deceased and then grasped again by the living to continue their own struggle. For those with a career or an identity beyond that of their family, memorials devoted exclusively to a career or to both a career and a family can console. But for those with nothing but a rotten job, meaning is often obtained from familial reproduction. In China,

10. For further discussion of Laclau and Mouffe, see Kipnis (2008).

2017 | HAU: Journal of Ethnographic Theory 7 (2): 217-238 
a discourse of "eating bitterness" as a form of familial sacrifice is commonplace (Kipnis 2016), and much of the rhetoric spoken at funerals and reproduced on tombstones exemplifies this discourse.

While familial reproduction might be seen as a theme with deep roots in premodern China, it is also modern. Moderns do not simply farm as their parents did. Rather, they must find a career or at least a job. For those who toil in alienating jobs, the meaning of work usually derives from the contributions to familial reproduction that income from the work enables. In this sense, devotion to family and the types of memorialization such devotion enables are not just vestiges of a premodern era but are central to modern life itself. Those who find meaning in a career are equally the products of modernity's division of labor.

The title of this essay echoes the title of Nikolas Rose's book, Governing the soul (1990), and his reading of modernity informs my take on the Chinese memorialization of souls. In particular, it is his emphasis on the rise of regimes of choice in modernity (rather than framing these regimes as neoliberalism or having Western origins) that illuminates modern practices of memorialization. When one's career, one's hobbies, one's religion, and even one's family become matters of individual choice, then a modern soul capable of choosing and finding motivation to stick by her choice must be cultivated. This evolution enables the differential interpretation of the family in analogic and naturalist ritual. In premodern ritual, the family forms an implicit doxa, an unquestionable starting point for life (Hsu 1971[1948]). In modern ritual it becomes an explicit reason for living, a counterweight to the alienating aspects of extrafamilial life. But the importance of family in both analogic and naturalist contexts enables the mixing of analogic and naturalist souls in death ritual.

The above depiction separates memorialization by the Party from the memorialization of "common folk," but I see no philosophical divide between political and nonpolitical memorialization. As I have argued elsewhere (Kipnis 2008), almost anything can be politicized. In China as elsewhere, the memorialization of a soul can lead to its politicization. The deaths of political leaders became rallying points in both the 1976 and 1989 protest movements centered at Tiananmen Square. The deaths of less famous individuals have also formed the basis for thousands of more localized protests in China-against corrupt and incompetent doctors; against employers who do not pay wages on time or do not offer adequate compensation for workplace injuries; against government decisions to limit the welfare or pension rights of various categories of people; against powerful people who cover up their liability in automobile accidents and the corruption that enables the cover-ups to proceed. Such protests lead me to read the "only-concrete-object-ism" of the Communist Party as not simply mistaken philosophy but as crass ideological manipulation. The Party knows that grief is a powerful emotion and that the memorialization of souls can easily give rise to a politicized spirit. The scientistic rhetoric of the Party toward funerals also leads to the blurring of analogic and naturalist souls by forcing most practice to take place under a veil of silence.

The hierarchies of death, reflected in the value of graveyard plots, the words contained in obituaries, or the number of people who attend and give gifts at a funeral, clearly cross the line between Party and society. The Party would like its hierarchies to be the only ones that matter. The Party has been somewhat successful

\section{7 | HAU: Journal of Ethnographic Theory 7 (2): 217-238}


in this regard as the value of graveyard real estate clearly rises when a large number of high-level cadres are buried there. But other forms of capital also influence funerary hierarchies.

In the logics of modernity, where individuals must choose their careers or jobs as well as their spouses and political causes, souls are needed to transcend the deaths of the individuals who make these choices. In a discussion of the relationship of transience to transcendence in acts of memorialization in Japan, Jason Danely states, "many older people found it meaningful to cultivate a sense of 'yielding' (yuzuri) to this passage of time, not only through passive resignation, but through actions that emphasized passing on tradition and values they felt deeply identified with. Transience of the individual, then, does not disrupt the overall cultural system, but motivates its narrative continuity" (Danely 2014:23). Here again, meaning in life is seen as coming from passing on a cultural soul that can transcend death.

If, following Descola, we accept that acts of memorialization are not so significant in animist and totemic societies, then what about the difference between analogic and naturalist memorialization? The forms of transcendence that I have been describing in the past few pages, whether involving the souls of cultural continuity depicted by Danely, the political propaganda of the CCP, or the careerist and familial souls of the masses, all involve the nature/culture dualism central to modern naturalist societies. ${ }^{11}$ Bodies are natural so they are mortal, but the souls of culture may be immortal. For the souls of culture to live on, they must be embodied by other humans. For hierarchies of humans to be constructed, the values enunciated by particular souls must be seen as more fully embodied by some bodies than others. Analogic souls can be read in a different light. In analogic societies, there is no strict line of difference between nature and culture, but there are subtle gradations of difference among a vast number of entities. Analogic interiorities come in many gradations and they do not only act in the world by animating physical human bodies. In China, ghosts, gods, and ancestors are all efficacious beings. As Heonik Kwon and Nguyen Van Huyen remind us for Vietnam, "the 'ancestors' presence in the domestic sphere is not in a mere passive state. The dead also act" (Nguyen, cited in Kwon 2006:84). Contemporary Chinese funerals blend naturalist and analogic souls. Perhaps the percentage of naturalist souls involved in Chinese funerals has increased and will continue to increase over time at the expense of analogical ones. But I doubt very much that such a shift will ever be total, absolute, ontological, or structural. Not only do analogic souls persist but also naturalistic souls have existed in China for a very long time. There have been state-designated martyrs and ideas about constructing traditions to transmit cultural souls for thousands of years.

11. While many criticisms of the nature/culture dualism have been leveled (for one summary see Helmreich 2014), and although Descola's book is titled Beyond nature and culture, the book reminded me of just how central the dichotomy remains to both modern (naturalist) thought in general and anthropology. Indeed, before reading the book I thought that I personally was over the distinction, but I am no longer so certain. The distinction is particularly apparent in modern practices of memorialization. Here, Michael Lambek's (2014) views of the nature/culture opposition are more appropriate than critiques that simply dismiss the opposition as irrelevant.

2017 | HAU: Journal of Ethnographic Theory 7 (2): 217-238 
In his depiction of so-called modern societies, Descola separates analogic and naturalist practices of commemoration much more clearly than can be done in China. He writes, "despite our pronounced taste for commemoration and despite the ceaseless celebration of heroes of the past ... there will be no trace among the Moderns of that subjugation to the ancestors" (Descola 2013:395). In China, this trace is quite evident. When a Chinese descendent burns incense at a home altar, or burns spirit money at a grave, or places cigarettes, food, and alcohol on a tombstone during Qing Ming, she does not specify whether she is venerating her father as an ancestor who can act in the present or paying respect to the modern naturalist spirit of his familial devotion. Similarly, when a rural tourist bows three times before the statue of Mao Zedong in his mausoleum, he does not specify whether he is worshipping Mao as a God who can act in this world or simply respecting the political spirit of the founder of the Chinese Communist Party. The distinction seems both impossible to draw and beside the point.

\section{Acknowledgements}

Grants from the Australian Research Council (DP140101294 and DP140101289) supported the research leading to this article. The anonymous readers for $H_{A U}$ as well as thoughtful audiences at the Australian National University, the Chinese University of Hong Kong, Nanjing University, London School of Economics, and Harvard University, provided valuable feedback. A heartfelt thanks to everyone!

\section{References}

Barmé, Geremie, ed. 1996. Shades of Mao: The posthumous cult of the great leader. Armonk, NY: M. E. Sharpe.

Chau, Adam Yuet. 2011. "Introduction: Revitalizing and innovating religious traditions in contemporary China." In Religion in contemporary China: Revitalization and innovation, edited by A. Y. Chau, 1-31. London: Routledge.

Cheater, A. P. 1991. "Death ritual as political trickster in the People's Republic of China." Australian Journal of Chinese Affairs 26: 67-97.

Chen, Huawen, and Shujun Chen. 2008. Wuyue Sanzang Wenhua (Funerary culture in the Wuyue area). Beijing: Huawen Chubanshe (Huawen Publishers).

Danely, Jason. 2014. Aging and loss: Mourning and maturity in contemporary Japan. New Brunswick, NJ: Rutgers University Press.

Descola, Philippe. 2013. Beyond nature and culture. Translated by J. Lloyd. Chicago: University of Chicago Press.

- 2014. "The difficult art of composing worlds (and replying to objections)." HAU: $^{-}$ Lournal of Ethnographic Theory 4 (3): 431-43.

Eickelkamp, Ute. 2017. "Finding spirit: Ontological monism in an Australian Aboriginal desert world today." HaU: Journal of Ethnographic Theorv 7 (1): 235-64.

\section{7 | HAU: Journal of Ethnographic Theory 7 (2): 217-238}


Feuchtwang, Stephan. 2014. "Too ontological, too rigid, too ahistorical but magnificent." HaU: Journal of Ethnographic Theorv 4 (3): 383-87.

Fong, Vanessa L. 2007. "Parent-child communication problems and the perceived inadequacies of Chinese only children." Ethos 35 (1): 85-127.

Frazer, James George. (1911) 1978. The illustrated golden bough. Abridged and illustrated by Sabine MacCormack. London: MacMillan.

Goossaert, Vincent, and David A. Palmer. 2011. The religious question in modern China. Chicago: University of Chicago Press.

Greenhalgh, Susan. 2003. "Planned births, unplanned persons: 'Population' in the making of Chinese modernity." American Ethnologist 30 (2): 196-215.

— 2008. Just one child: Science and policy in Deng's China. Berkeley: University of California Press.

Greenhalgh, Susan, and Edwin A. Winckler. 2005. Governing China's population. Stanford, CA: Stanford University Press.

Helmreich, Stefan. 2014. "Waves: An anthropology of scientific things." HaU: Journal of Ethnographic Theorv 4 (3): 265-84.

Hsu, Francis L. K. (1948) 1971. Under the ancestors' shadow: Kinship, personality, and social mobility in China. Stanford, CA: Stanford University Press.

Ji, Zhe. 2011. "Buddhism in the reform era: A secularized revival?" In Religion in contemporary China: Revitalization and innovation, edited by A. Y. Chau, 32-52. London: Routledge.

Kaiman, Jonathan. 2015. “China's funeral revolutionaries." Guardian, September 8. www.theguardian.com/world/2015/sep/08/.

Kapferer, Bruce. 2014. “Back to the future: Descola's neostructuralism.” HAU: Journal of Ethnographic Theorv 4 (3): 389-400.

Kipnis, Andrew B. 2001. "The flourishing of religion in post-Mao China and the anthropological category of religion.” Australian Journal of Anthropology 12 (1): 32-46.

- 2008. China and postsocialist anthropology: Theorizing power and society after communism. Norwalk, CT: Eastbridge.

- 2016. From village to city: Social transformation in a Chinese county seat. Berkeley: University of California Press.

—. Forthcoming. “The universality of sex and death." American Anthropologist.

Kwok, David W. Y. 1965. Scientism in Chinese thought. Berkeley: University of California Press.

Kwon, Heonik. 2006. After the massacre: Commemoration and consolation in Ha My and My Lai. Berkeley: University of California Press.

Laclau, Ernesto, and Chantal Mouffe. 2001. Hegemony and socialist strategy: Towards a radical democratic politics. London: Verso.

Lambek, Michael. 2014. “The elementary structures of being (human).” HaU: Journal of Ethnooraphic Theory 4 (3): 411-17. 
Laqueur, Thomas W. 2015. The work of the dead: A cultural history of mortal remains. Princeton, NJ: Princeton University Press.

Lenclud, Gerard. 2014. "From one ontology to (an)other." HaU: Journal of Ethnographic Theory 4 (3): 363-72.

Liu, Ziqing. 2014. "Babaoshan Man Yuan (Babaoshan is full)." Dong Xi Nan Bei (Four Directions) 8:48-49.

Makley, Charlene. 2015. "The sociopolitical lives of dead bodies: Tibetan self-imolation protest as mass media." Cultural Anthropology 30 (3): 448-76.

Matthews, William. 2017. "Ontology with Chinese characteristics: Homology as a mode of identification." HaU: Journal of Ethnographic Theorv 7 (1): 265-85.

Piao, Vanessa. 2016. "China, facing land shortages, encourages saving space 6 feet under." New York Times, February 26. http://nyti.ms/1p7LXct.

Rose, Nikolas. 1990. Governing the soul: The shaping of the private self. London: Routledge.

Tsai, Wen-Hsuan. 2017. "Framing the funeral: Death rituals of Chinese Communist Party leaders.” China Journal 77:51-71.

Tylor, Edward Burrnett. 1871. Primative culture: Researches into the development of mythology, philosophy religion, art and custom. 2 vols. London: John Murray.

van der Veer, Peter. 2012. "Smash temples, burn books: Comparing secularist projects in India and China." World Religious Cultures (Shijie Zongjiao Wenhua) 73:17-25.

Verdery, Katherine. 1999. The political lives of dead bodies. New York: Columbia University Press.

Wakeman, Frederic. 1988. "Mao's remains." In Death ritual in late imperial and modern China, edited by James L. Watson and Evelyn S. Rawski, 254-88. Berkeley: University of California Press.

Wang, Jisheng, ed. 2002. Shi Si Ru Sheng: Binzang Lilun Yu Zhongguo Wenhua (Death ritual as life: Funerary theory and Chinese culture). Shanghai: Baijia Chubanshe (Baijia Publishers).

Wang, Zhong, and Yongtong Su. 2011. "Chu Babaoshan, Lingdaoren Anzang He Chu (Leaving Babaoshan, where are the leaders buried)." Zhong Wai Wenzhai (China and the World Periodical Digest) 15: 8-10.

Wardega, Joanna. 2012. "Mao Zedong in present-day China: Forms of deification." Politics and Religion in Contemporary China 6 (2): 181-96.

Wei, Yan, and Li Zhang. 2014. "Re-examination of the Yicheng two-child program.” China Lournal 72:98-120.

Whyte, Martin King, Wang Feng, and Yong Cai. 2015. “Challenging myths about China’s one-child policy." China Journal 74:144-59.

Yang, Mayfair Mei-hui, ed. 2008. Chinese religiosities: Afflictions of modernity and state formation. Berkeley: University of California Press.

Yu, Hua. 2013. Di Qi Tian (The seventh day). Beijing: New Star Press.

—. 2015. The seventh day (Di Qi Tian). Translated by A. H. Barr. New York: Pantheon.

2017 | HAU: Journal of Ethnographic Theory 7 (2): 217-238 
Zhao, Kiki. 2016. "China’s new wedding vows: To have, hold and not violate national interests.” New York Times, February 18. https://www.nytimes.com/2016/02/19/world/asia/ china-communist-party-weddings-funerals.html.

\section{Gouverner les Ames de la Modernité Chinoise}

Philippe Descola suggère que les sociétés humaines peuvent être catégorisée en fonction de leur manière de concevoir de larges hypothèses sur la nature de l'intériorité et de la physicalité; l'intériorité signifiant ici quelque chose de comparable à ce qu'Edward Tyler et James Frazer appelaient "lâme". D’après Descola, la culture chinoise, qui offre une variabilité infinie à l'intériorité et à la physicalité, est une culture de "l'analogisme." Par contraste, Descola définit les sociétés occidentales modernes comme "naturalistes." Nous autres modernes voyons la nature et la physicalité comme universellement fixées, mais la culture et l'intériorité comme variables. La Chine contemporaine et sa culture scientifique se modernisent rapidement. Dans les termes de Descola, cette culture devrait connaître une transformation d'analogisme à naturalisme. A travers une analyse des pratiques de commémoration et des rites funéraires en Chine urbaine, ainsi que des tentatives du Parti Communiste Chinois de contrôler les évolutions de ces pratiques en réaction à la "modernité," cet essai montre ce qui est moderne à propos des conceptions de lâme implicites dans les pratiques ayant lien à la mort en Chine contemporaine.

Andrew B. KIPNIS is a Professor of Anthropology in the Chinese University of Hong Kong. He is the author of five books including most recently From village to city: Social transformation in a Chinese county seat (University of California Press, 2016). Previous works include China and postsocialist anthropology (Eastbridge, 2008) and Governing educational desire (University of Chicago Press, 2011). For ten years he was editor of the China Journal.

Andrew B. Kipnis Department of Anthropology Chinese University of Hong Kong Shatin, New Territories Hong Kong Andrew.kipnis@anu.edu.au 